\title{
FEATURE The impacts of 2011 induced levee breaches on agricultural lands of Mississippi River Valley
}

\author{
Kenneth R. Olson and Lois Wright Morton
}

T o control the Mississippi River is a mighty task (Barry 1997), and the 2011 flooding of its alluvial valley was a reminder of just how difficult this task can be. Heavy snow melt and rainfall ten times greater than average across the eastern half of the $517,998 \mathrm{~km}^{2}(200,000$ $\mathrm{mi}^{2}$ ) Mississippi watershed in spring and early summer of 2011 produced one of the most powerful floods in the river's known history (USACE 2011). The water from the Mississippi and Ohio rivers arrived in the Cairo, Illinois, area (figure 1) at about the same time, straining the levees and floodwall system designed to confine the rivers and protect cities and farmlands.

The deliberate breaching of the levees in the New Madrid Floodway below Cairo in May 2011 was a planned strategy to reduce water pressure and prevent levee failures where harm to human life might occur. The induced breach and the flooding of 53,824 ha $(133,000 \mathrm{ac})$ of Missouri farmland resulted in the loss of 2011 crops and damage to future soil productivity. The strong current and sweep of water through the Birds Point, Missouri, breach created deep gullies, displaced tons of soil, and damaged irrigation equipment, farms, and home buildings.

The starting point of the lower Mississippi River is the confluence of the Mississippi and the Ohio rivers at Cairo, Illinois, $85 \mathrm{~m}(279 \mathrm{ft})$ above sea level. In the aftermath of the deadly 1927 flood, the US Army Corps of Engineers (USACE) designed the New Madrid Floodway project as part of a larger Mississippi River Basin plan to manage the river and control flooding when the Ohio and Mississippi rivers converge and threaten to overflow the frontline levees and seawalls that contain these rivers. The New Madrid Floodway

Kenneth R. Olson is professor of soil science in the College of Agricultural, Consumer, and Environmental Sciences, University of Illinois, Urbana, Illinois. Lois Wright Morton is professor of sociology in the College of Agriculture and Life Sciences, lowa State University, Ames, lowa.

\section{Figure 1}

Map of the Ohio and Mississippi River confluence and Mississippi River from Cairo, Illinois, to New Madrid, Missouri.

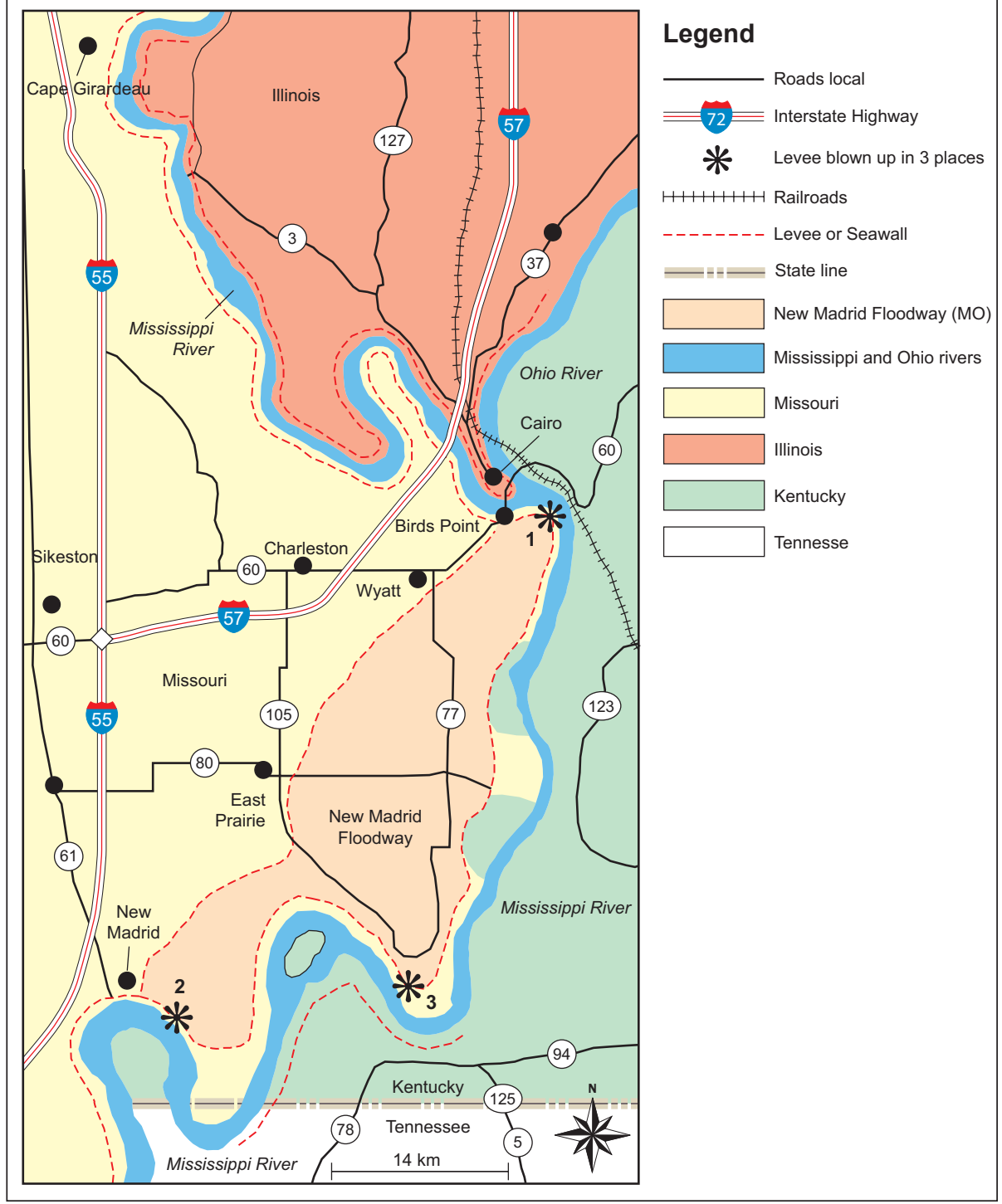

(figure 1) and border levees (figure 2) were built under the authority of Flood Control Act of 1928 (70th US Congress, Session 1 Chapter 596, enacted May 15, 1928) (FCA 1928). The Floodway is approximately $53.1 \mathrm{~km}(33 \mathrm{mi})$ long and is between 6.4 $\mathrm{km}(4 \mathrm{mi})$ and $16.1 \mathrm{~km}(10 \mathrm{mi})$ wide. The Floodway is enclosed by frontline and setback levees, except for a $457 \mathrm{~m}(1,500$ $\mathrm{ft}$ ) gap at the lower end which serves as a drainage outlet and allows flood backwaters to enter the Mississippi River. The frontline levee includes a $17.7 \mathrm{~km}(11 \mathrm{mi})$ long upper fuse plug section, an $8 \mathrm{~km} \mathrm{(5}$ mi) long lower fuse plug section, and the $24 \mathrm{~km}$ (16 mi) long frontline levee section connecting the two plugs. The frontline levee, which forms the eastern boundary of the Floodway, was constructed to protect the Floodway until the Mississippi River reached the $16.8 \mathrm{~m}(55 \mathrm{ft})$ stage, at which time the floodwater would naturally overtop the frontline levee. This did happen during the flood of 1937. The set- 


\section{Figure 2}

The New Madrid Floodway and Basin still has 2 to 3 m of floodwater on May 20, 2011.

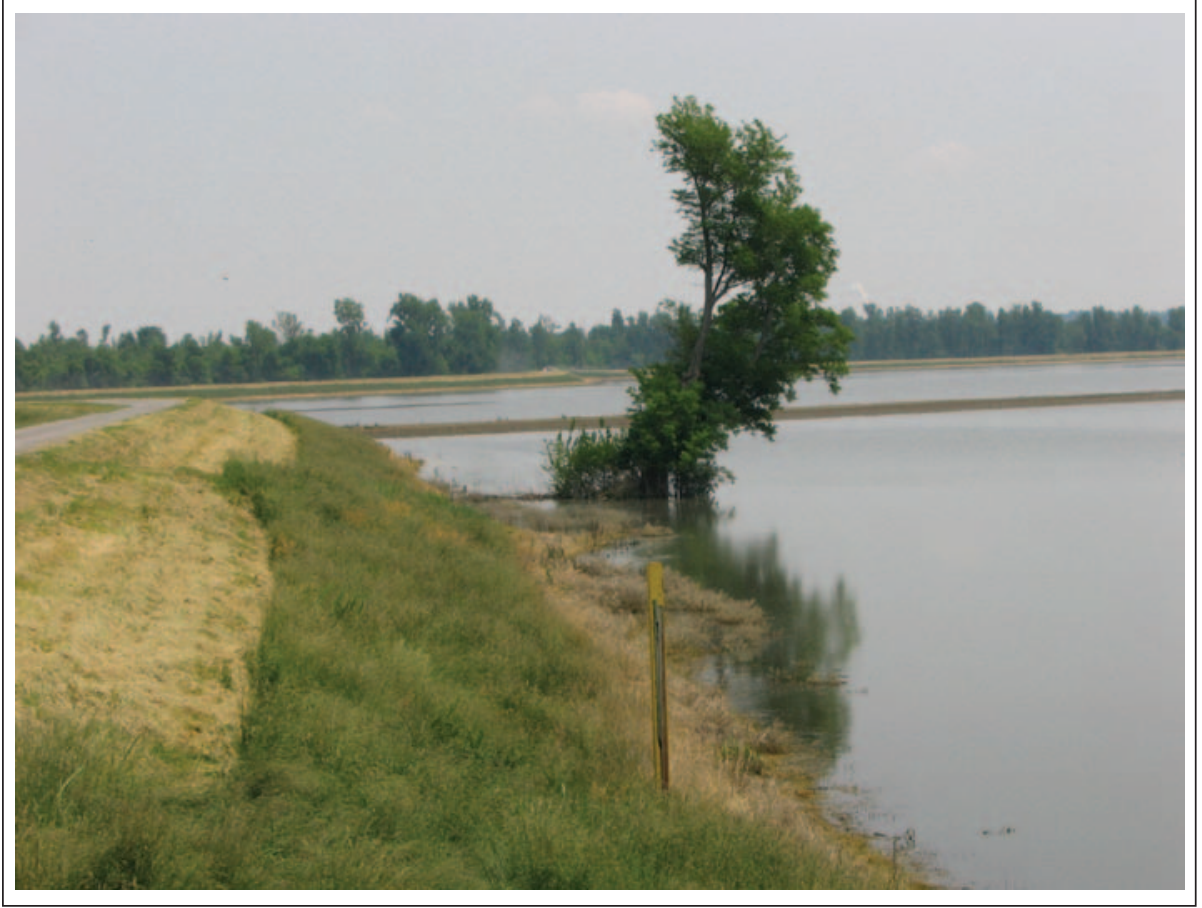

back levee is $57.9 \mathrm{~km}$ (36 mi) long and goes from Birds Point, Missouri, to New Madrid, Missouri (figure 1). The USACE obtained easements in 1928 with the land owners on the 53,824 ha $(133,000 \mathrm{ac})$ of the New Madrid Floodway, which gave them the right to pass floodwater into and through the New Madrid Floodway and temporarily store floodwater in the basin.

Congress authorized modification of the New Madrid Floodway operational plan in the Flood Control Act of 1965 (Public Law 89-298, 89th US Congress, enacted October 27, 1965) (FCA 1965). The plan called for raising the upper and lower fuse plugs to $18.4 \mathrm{~m}(60.5 \mathrm{ft})$, the frontline levee to $19.1 \mathrm{~m}(62.5 \mathrm{ft})$, and the setback levee to $20 \mathrm{~m}(65.5 \mathrm{ft})$. The Floodway plan also called for artificial crevassing (breaking or breaching) of the levee by means of explosives on only the upper fuse plug section of the frontline levee when river stages were at or above $17.7 \mathrm{~m}(58 \mathrm{ft})$ on the Cairo gauge with a prediction that stages would exceed 18.3 $\mathrm{m}$ (60 ft). The plan envisioned that natural breaching might occur in the lower fuse plug section in the event of a flood of that magnitude (such as the flood of 1937). After approval of the 1966 plan, the levee landowners and enjoined the Secretary of US Army and subordinates from artificially crevassing (breaching) the frontline levee. The District Court determined that the 1983 USACE new plan was not authorized by Congress and instead relied on the 1965 Flood Control Act for the authority to operate and maintain the Floodway as well as to implement the new 1983 operational plan. If the District Court ruling that denied condemnation and immediate possession was reversed, the District Court required that the federal government escrow in anticipated levee repairs a deposit of US\$6,400,000 for Levee District No. 3 and US\$4,000,000 for St. John's Levee and Drainage District. This "just compensation" estimate was based on the amount the District Court determined would be necessary to restore the levees and the operation of the Floodway.

However, on April 13, 1984, the US Court of Appeals for the Eighth Circuit reversed all of the District Court rulings and permitted the USACE to artificially crevasse (breach) the frontline and fuse plug levees and negated the need for the escrow deposit. Eighth Circuit Court determined that the 1965 Flood Control Act gave the authority to the USACE to operate the New Madrid Floodway and as such already required them to restore the levees after any artificially breaching events. This case law became the legal precedent used by the Federal court system in 2011 to decide a last-minute appeal by landowners in the Floodway to prevent the Corps from blowing up the frontline levee once the Cairo levee and seawall floodwaters reached $17.7 \mathrm{~m}(58 \mathrm{ft})$ with a forecast of $18.3 \mathrm{~m}(60 \mathrm{ft})$ or higher peak. Consequently, floodwaters continued to rise through April and until May 1, 2011, when the Supreme Court affirmed the USACE right to blow up parts of the frontline levees and pass water into and through the New Madrid Floodway and on basin soils (Caruthersville very fine sandy loam, Commerce silty clay loam, Dundee silt loam, and Forestdale silt loam) (Brown 1977; DeYoung 1924). The amount of temporary water storage (at initial depths from 1.8 to $3.7 \mathrm{~m}$ [6 to $12 \mathrm{ft}]$ ) and pass-through water in the New Madrid Floodway was 25 to 28 times 
greater than what could have been stored in the Cairo and Future City, Illinois, areas and adjacent agricultural areas of Illinois if the Cairo and Future City seawalls or levee system were naturally breached. The impacts of the 2011 Mississippi River and Ohio River flooding on Cairo, Illinois, is the focus of an upcoming article in the March-April 2012 issue of the Journal of Soil and Water Conservation (Olson and Morton forthcoming).

The induced breach at Birds Point, Missouri, the first explosion site (figure 1) and flooding of the New Madrid Floodway and basin on May 2, 2011, resulted in no loss of life thanks in part to the US National Guard sweep of the area to make sure the people living and working in the Floodway were evacuated. The force and impact of the floodwater on the $470 \mathrm{~km}^{2}\left(208 \mathrm{mi}^{2}\right)$ of the Floodway may have been greater than projected in the 1983 Corps of Engineers operational plan. The Floodway was subjected to rapidly moving floodwaters which were initially $1.2 \mathrm{~m}$ (4 ft) deeper than would have been released if the fuse plug was blown when the Cairo levee was at $17.7 \mathrm{~m}(58 \mathrm{ft})$. There was severe damage to most of the 200 or more buildings, including homes, which were exposed to 0.9 to $1.8 \mathrm{~m}(3$ to $6 \mathrm{ft}$ ) of flowing water and then partially submerged in 1.8 to $3 \mathrm{~m}$ (6 to 10 $\mathrm{ft}$ ) of floodwater. Water pressure caused loss of the lower one-third to one-half of entire walls, damaged most wooden floors, and in some cases completely destroyed structures.

On May 3, 2011, the lower plug levee was blown up near New Madrid, Missouri, the second explosion site (figure 1) to begin the return of the stored floodwater back into the Mississippi River (figure 1). However, the Mississippi River was still too high to allow a quick drop in the floodwater in the New Madrid Floodway. The USACE planned to blow up the frontline levee near Big Oak Tree State Park in Missouri, the third explosion site (figure 1), on May 4, 2011, but weather and shortage of TNT delayed the third explosion until May 5, 2011. It appears for the next few days that the Mississippi River floodwater at the third breached levee site actually flowed out for days before it flowed back in since the Mississippi River the inward flow includes a crater lake adjacent to the west side of the frontline levee and a sand deposit west of the frontline levee rather than to the east (Olson 2009). Local farmers reported that Mississippi River water did flow out initially on May 5, 2011, but 14 days later started to flow rapidly in through this 3 rd frontline levee breach, creating a 6.4 ha (16 ac) lake, gullies, and a thick 100 ha $(250 \mathrm{ac})$ sand deltaic deposit. Over the next few weeks, the New Madrid Floodway continued to drain through the New Madrid breach, and the floodwater in the Floodway basin dropped to between 0.6 and $2.1 \mathrm{~m}$ (2 and $7 \mathrm{ft}$ ) depending on the elevation of bottomland soils; however, 0.9 to $2.1 \mathrm{~m} \mathrm{(3} \mathrm{to}$ $7 \mathrm{ft}$ ) of floodwater still remained and covered both cropland and pastureland.

\section{FLOODED AGRICULTURAL LANDS}

From an agricultural production point of view, the 53,824 ha $(133,000 \mathrm{ac})$ of cropland in the New Madrid Floodway was only partially planted to corn and soybeans due to a very wet April. However, there was extensive acreage $(8,094$ to 12,146 ha $[20,000$ to $30,000 \mathrm{ac}])$ of wheat planted in the fall of 2010 that was $0.3 \mathrm{~m}$ (1 ft) tall but had not reached grain fill stage remained above flood stage. Evidence of

when the Floodway was opened on May 2, 2011, flooding agricultural fields with 1.8 to $3 \mathrm{~m}$ ( 6 to $10 \mathrm{ft}$ ) of water. There was

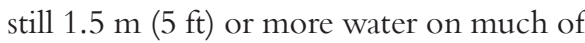
the farmland as of May 20th and it took a drop in the Mississippi River to drain most of the remaining floodwater. By June 6th, approximately 36,042 ha $(90,000 \mathrm{ac})$ had no floodwater on the surface, and some of the land had dried sufficiently to begin the soybean planting. There was about 12,146 ha $(30,000 \mathrm{ac})$ (figure 2) still covered with water at the south end of the Floodway near New Madrid, Missouri, and about 4,047 ha $(10,000 \mathrm{ac})$ near Wyatt and Birds Point, Missouri, on June 6th. By June 15th, more than 30 excavators were working to clean out sediment and to remove debris that were blocking drainage ways and ditches to speed up the drainage process (figure 3 ). The sediment in private drainage ways of most qualified land owners was removed with a $75 \%$ cost share from the USDA Farm Services Agency's Emergency Conservation program. It took until October 2011 for the last 12,146 ha $(30,000 \mathrm{ac})$ to dry out sufficiently to allow tractor traffic and planting of wheat in fall of 2011.

Many farmers in the central part of the New Madrid Floodway were able to begin planting soybeans by June 5 th on areas

\section{Figure 3}

Excavator cleaning out sediment in road ditches. Photo courtesy of Brett Miller, Soil Conservation Technician, USDA Natural Resources Conservation Service.

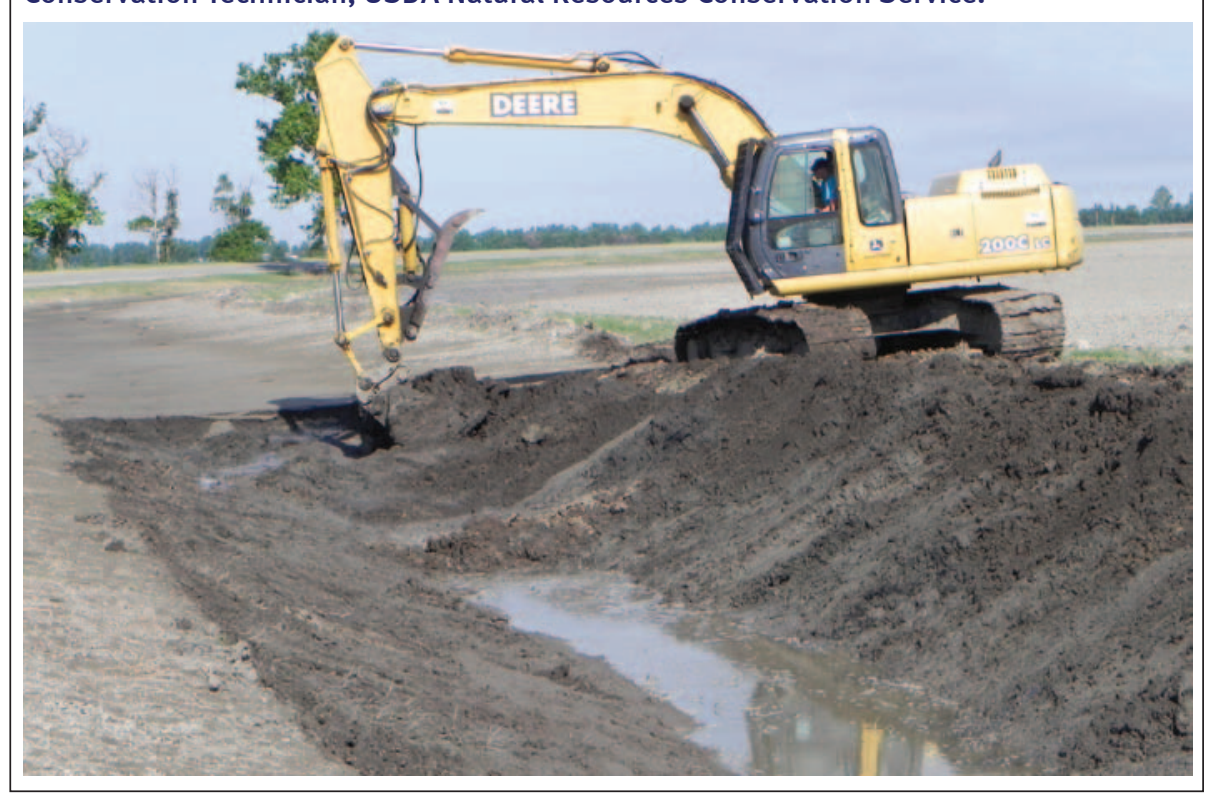


with loamy and silty soils (Caruthersville very fine sandy loam, Commerce silty clay loam, and Dundee silt loam) (Brown 1977). These soils had good internal drainage and were on higher areas with less initial depth of floodwaters. As many as 12,146 ha $(30,000 \mathrm{ac})$ of soybeans were planted by June 15 th, and another 12,146 ha $(30,000 \mathrm{ac})$ of soybeans were planted before July 15th (last date for planting soybeans in the area) as ponded areas and lakes shrank and more soils dried out. As anticipated, the approximately 16,188 ha $(40,000 \mathrm{ac})$ that were under water on June 5 th remained too wet to plant to soybeans by July 15 th, and at least half $(8,094$ ha $[20,000 \mathrm{ac}])$ of these areas were planted to wheat in fall of 2011. The other 8,094 ha on low-lying areas with clayey soils (Sharkey silty clay loam and Alligator silty clay) (Brown 1977) with low permeability will likely not be planted to either corn or soybeans until spring 2012. These soils are not well suited to wheat production, so it does appear that the crop loss in 2011 will be the 8,094 to 12,146 ha $(20,000$ to $30,000 \mathrm{ac}$ ) of wheat planted in fall of 2010 and drowned in early May of 2011 and the additional 8,094 ha $(20,000 \mathrm{ac})$ of low-lying clay soils that remained ponded until late in summer of 2011.

Almost all of the 2010 winter wheat drowned before filling with grain, and the wheat fields collected more sediment (10 to $15 \mathrm{~cm}$ [ 4 to $6 \mathrm{in}$ ]) than the fields with corn and soybean residue from last year's crop (less than $5 \mathrm{~cm}[2 \mathrm{in}]$ ). Most of the 2011 soybeans were planted after chisel plowing or in some cases using a no-till planting system. It is anticipated that most of the Floodway agricultural lands without winter wheat planted in fall of 2011 will be planted to corn and soybeans in the spring of 2012. Some of these areas may be double cropped in 2012, with soybeans planted and harvested and then wheat planted in the fall. It now appears that about one-third of the entire 53,824 ha $(133,000 \mathrm{ac})$ of highly productive agricultural land will be out of production for a minimum of 1 year, including some areas where the wheat crop drowned and clayey soils were too wet to plant to soybeans by July 15 and not suited to wheat production. Consequently, there will be an adverse effect on farm incomes and possibly wheat and corn supplies. Apparently, for insurance purposes, the humaninduced flooding will be treated as natural flooding or the same as if the levee breach occurred naturally.

\section{GULLY FIELDS AND SEDIMENT TRANSPORT}

Significant crater lakes existed in June of 2011 at two locations where the explosives (TNT) were used (Birds Point, Missouri, fuse plug and frontline levee near Big Oak Tree State Park, Missouri). The extreme force of the rushing water widened the holes in the levees $(2 \mathrm{~km}[1.24 \mathrm{mi}])$ at Birds Point fuse plug and created 6 crater lakes in the levee fuse plug and adjacent to it. Each Birds Point crater lake was approximately 0.5 ha $(1.3 \mathrm{ac})$ in size. At a few Birds Point sites, there were gullies extending into the fields from the crater lakes and subsequent creation of a deltaic sand deposit that was 0.3 to $1.5 \mathrm{~m}$ (1 to $4.6 \mathrm{ft}$ ) thick and approximately 3 to 20 ha $(7.4$ to $49.4 \mathrm{ac})$ in size. Both the crater lakes and the thick sand deposits will result in a permanent loss of agricultural land (Olson 2009) unless the sand is returned to the crater lakes or removed or used in the patched levee. The frontline levee near Big Oak Tree State Park had only one 6.4 ha $(16 \mathrm{ac})$ crater lake extending through the levee and to the west (away from Mississippi River) and a thick 1 to $2 \mathrm{~m}$ (3.3 to $6.6 \mathrm{ft}$ ) deltaic sand deposit approximately 30 ha $(74 \mathrm{ac})$ in size with additional sand deposits between 0.3 and $1 \mathrm{~m}$ (1 to $3.3 \mathrm{ft})$ more than $70 \mathrm{ha}(173 \mathrm{ac})$ in size. This thick deltaic sand deposit requires removal before land can be returned to agricultural use.

The road and drainage ditches along Highway 77 in Mississippi County approximately 4 to $6 \mathrm{~km}$ (2.5 to $3.7 \mathrm{mi})$ south of Wyatt, Missouri, were filled with 0.9 to $1.8 \mathrm{~m} \mathrm{(3} \mathrm{to} 6 \mathrm{ft}$ ) of sediment and sand. Figure 3 shows an excavator remov-

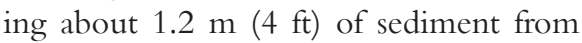
the road ditch. Irrigation systems were occasionally overturned by the force of water and wind and then buried by deltaic sand deposits (figure 4).

If the thin, organic silt and clay coatings are mixed into the topsoil in 2011 or

\section{Figure 4}

An irrigation system was overturned by the force of floodwater and wind and then buried by thick sand deposit. Photo courtesy of Brett Miller, Soil Conservation Technician, USDA Natural Resources Conservation Service.

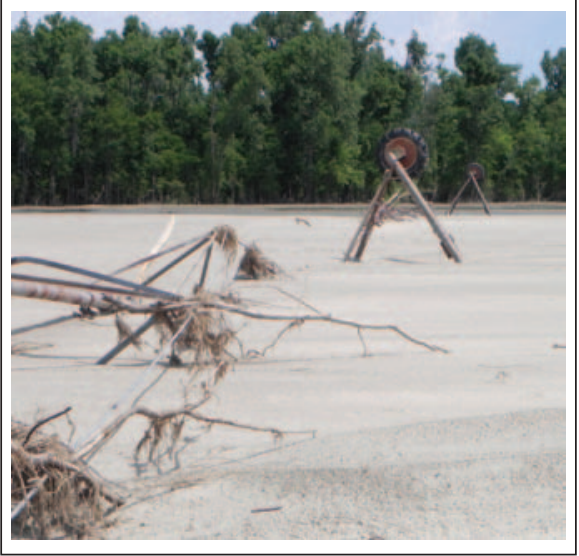

2012, little significant loss in future crop yield will occur as long as the Floodway is not flooded again. By early June, the Floodway water dropped enough for a USDA Natural Resources Conservation Service led survey team to start determining the extent of the damage to the agricultural land. Preliminary findings suggest that considerable sediment deposition (few centimeters [few inches]) occurred in drainage ditches and on the wheat fields. In addition, there are several hundred hectares (few hundred acres) of cropland with deep gullies (figure 5) created on ridges that were scoured (eroded) as the rapidly moving initial water flowed with an extra $1.2 \mathrm{~m}$ (4 ft) depth. Huge fields with gullies (figure 6) were found on higher natural levee or second bottom Dundee silt loam soils (Brown 1977) or on ridges (such as O'Bryan's Ridge south of Wyatt, Missouri) when floodwaters flowed rapidly over the higher flat land surface and then dropped back to lower (first bottom) soils to the west and south. This rapid dropping of floodwater created turbulence and eroded the higher Dundee silt loam soils. Once an erosional channel was created, the channel concentrated the water and in some cases up to $1 \mathrm{~km}(0.6$ mi) long gullies (channels) were created. These gully fields are primarily located 8 to $16.1 \mathrm{~km}$ (5 to $10 \mathrm{mi}$ ) to the south and west of the Birds Point levee breach and are not connected to the crater lakes 


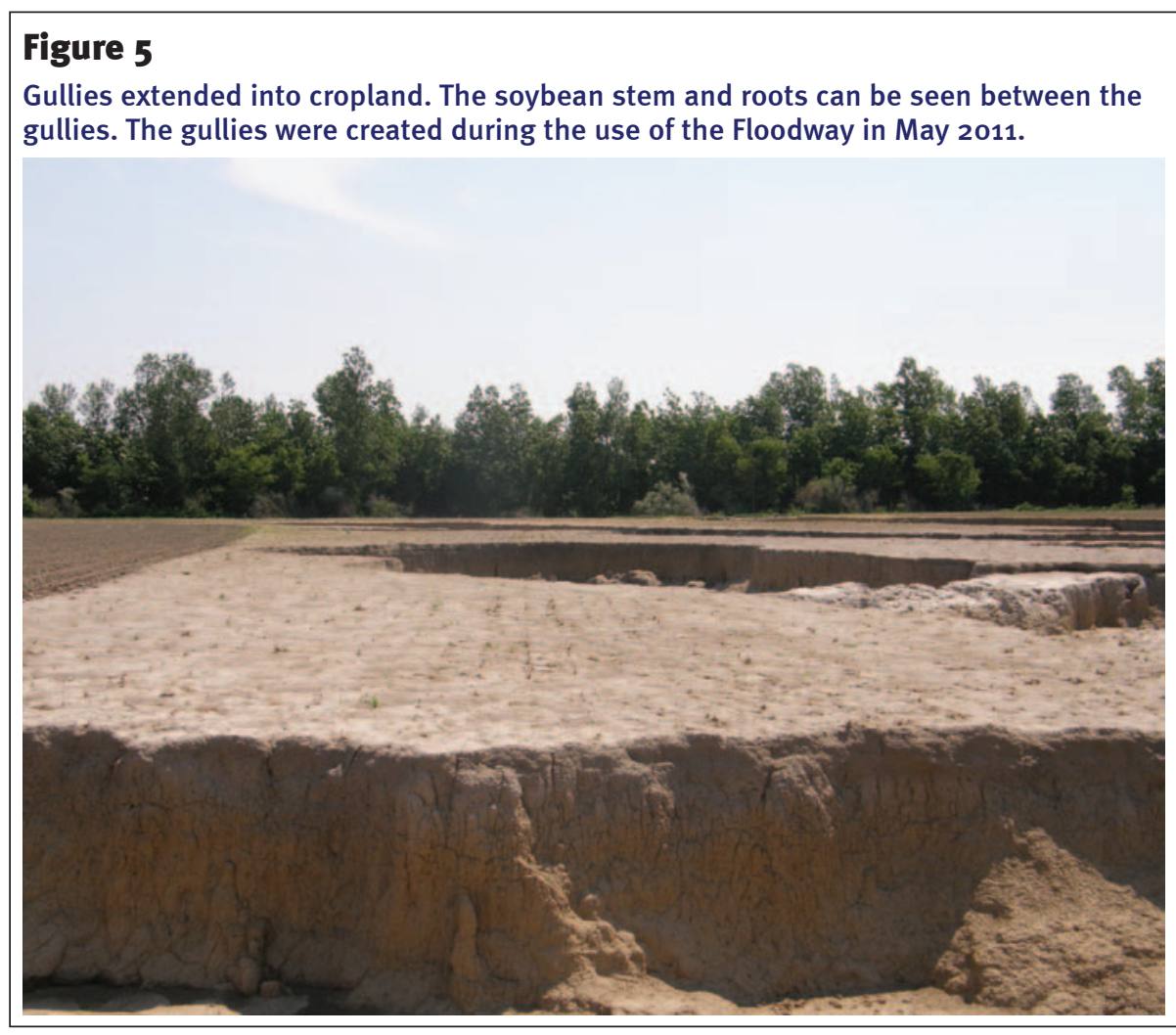

\section{Figure 6}

Gullies and channels that were created from May 4 to 16, 2011. The main channel and attached gullies were $3.7 \mathrm{~m}$ deep and removed more than 4 ha of cropland with an additional 4 ha of dissected field which could not be cultivated.

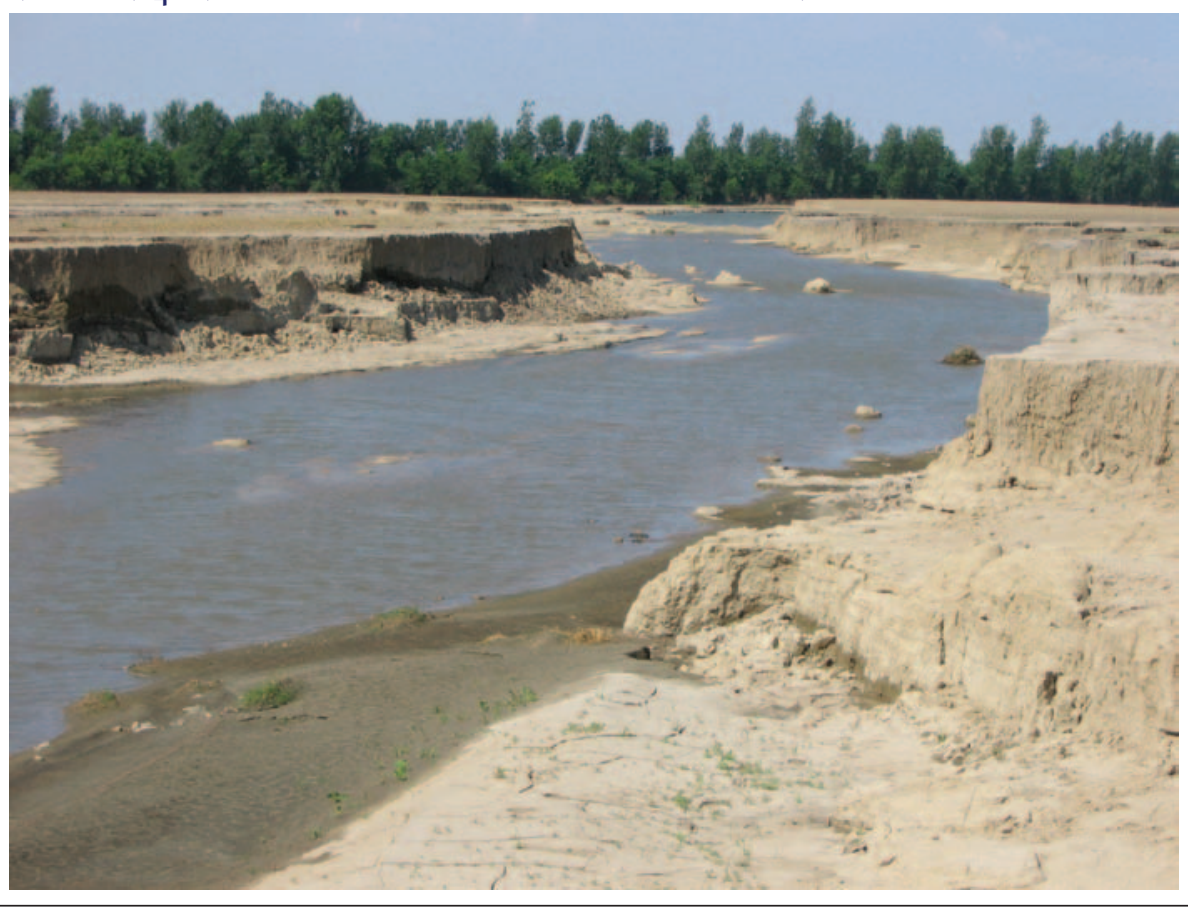

next to the levee breaches. Some of the gullies are $3.7 \mathrm{~m}(12 \mathrm{ft})$ deep, $45.8 \mathrm{~m} \mathrm{(150}$ $\mathrm{ft}$ ) wide, and $1 \mathrm{~km}(0.6 \mathrm{mi})$ long (figure 6$)$. A number of fields have these gullies, and sometimes less than one-half of each field was planted to soybeans in June 2011. The force of water which created these large gullies (approaching small canyons in size) also removed road beds and resulted in the loss of bridges.

These gully lands will be extremely difficult to reclaim, and it is not clear how the land can be fully restored. The total amount of soil loss in metric tons has not been calculated, and the source of replacement soil will be difficult and costly to locate. Another option would be to regrade the vertical walls and reshape the fields with gullies into smooth rolling lands by filling in deepest craters with soil from the side slopes and crater walls. The new soils would be less productive than the previous alluvial soils (Olson and Lang 2000) due to the lower soil organic carbon content, greater slope, and lack of topsoil and subsoil material in the root zone. There is a health concern related to any pollutants that might be in floodwaters, such as untreated sewage from plants that were flooded or other chemicals picked up by floodwaters. When the organic and clay particles coating the plants and soils are dried, it is likely that sunlight will kill pathogens that might be present. Tillage could be used to bury or mix this potentially toxic coating into the topsoil layer, which will treat or dilute any toxic chemicals present. It is not known whether the soil organic carbon content of the alluvial soils would be increased as a result of sediment and exposure to carbon rich floodwater. It is anticipated that microbes will decompose the carbon deposited with the sediment or in the thin surface coating and release the carbon to the atmosphere as either carbon dioxide or methane gases, depending on whether there are aerobic or anaerobic conditions at the time the microbes are active.

\section{CONCLUSION AND IMPLICATIONS}

The decision to blow up the Birds Point fuse plugs and frontline levees had significant consequences for rural Missouri landowners, farmers, and residents in the New Madrid Floodway. The impact of the floodwaters on the Floodway appears to have been greater than anticipated in part as a result of the delay in opening the Floodway due to legal action. When the US Army Corps of Engineers were given permission to open the Floodway, the Mississippi River was $1.2 \mathrm{~m}$ (4 ft) higher 
than planned for, and the initial additional force and depth of floodwater caused more damage to buildings and more deep land scouring than was predicted. Impacts included the loss of the 2011 wheat crop and of crop production from perhaps 8,094 to 12,146 ha $(20,000$ to $30,000 \mathrm{ac})$ of poorly drained clayey soils that were not replanted in 2011. Most of the farmland in Floodway dried out sufficiently to permit fall planting of wheat. It appears that all of the Floodway will be sufficiently dry by spring of 2012 (weather permitting) to allow the planting of corn and soybeans. It is not clear how much of 2011 farm income replacement will come from flood insurance since not all Floodway farmers had crop insurance. Over 1 million ha (2.5 million ac) of agricultural bottomlands in Missouri and Arkansas were protected by the hundreds of kilometers (hundreds of miles) of levees on the west side of the Mississippi River below New Madrid, Missouri, and west of the Floodway setback levee. These levees did not fail before, during, or after the use of the Floodway, and the 2011 agricultural production from this region was maintained.

There could be a permanent loss of some agricultural production on hundreds of hectares (hundreds of acres) of land due to large deep gullies, on those parcels adjacent to the blown levees that are covered with a thick sand deposit, and on farmland that is now in the new crater lakes. Reclamation efforts by the US Army Corps of Engineers have removed much of the thick sand deposits, and the sand was used to patch the frontline and fuse plug levees between Birds Point, Missouri, and New Madrid, Missouri, or to partially fill in the crater lakes and adjacent gullies. Filled crater lakes at Birds Point have been covered with topsoil trucked in from outside the Floodway. The earthen levee

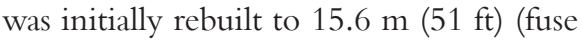
plug was previously at $18.4 \mathrm{~m}[60.5 \mathrm{ft}]$ and

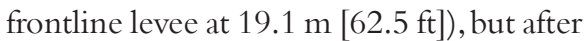
input from the local farmers and additional federal funding, the rebuilt levee was raised

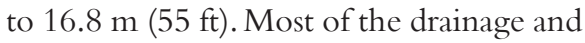
road ditches which were filled with sediment were cleaned out by excavators prior to October of 2011 and proper drainage was restored. However, the unanticipated fields with large and deep gullies will not easily be repaired. It will be rather difficult to reshape and regrade these gullies in isolated cultivated fields on ridges or second bottom soils. These fields of gullies could cause the permanent loss of agricultural land unless a federally funded land reclamation program is developed. Even if the fields of gullies are reclaimed, these soils are likely to have lower productivity. In many cases, the alluvial parent material will become the land surface and will have less soil aggregation, have less soil organic carbon, and be more sloping. The reclamation effort could restore some of the permanently lost cropland in crater lakes and sand delta and/or create additional wetlands and wildlife habitat adjacent to the patched levees.

\section{REFERENCES}

Barry, J.M. 1997. Rising Tide: The Great Mississippi Flood of 1927 and How it Changed America. New York: Simon \& Schuster.

Brown, B.L. 1977. Soil Survey of New Madrid County, Missouri. Washington, DC: USDA Natural Resource Conservation Service.
DeYoung,W. 1924. Soil Survey of Mississippi County, Missouri. Washington, DC: USDA Bureau of Soils.

FCA (Flood Control Act). 1928. http://www.mvd. usace.army.mil/mrc/history/AppendixE.htm.

FCA. 1965. http://www.fws.gov/habitatconservation/Omnibus/R\&HA1965.pdf.

Olson, K.R. 2009. Impacts of 2008 flooding on agricultural lands in Illinois, Missouri, and Indiana. Journal of Soil and Water Conservation 64(6):167A-171A.

Olson, K.R., and J.M. Lang. 2000. Optimum crop productivity ratings for Illinois soils. Bulletin 811. Urbana, IL: University of Illinois, College of Agricultural, Consumer and Environmental Sciences, Office of Research.

Olson, K.R., and L.W. Morton. Forthcoming. The effects of 2011 Ohio and Mississippi River valley flooding on Cairo, Illinois, area. Journal of Soil and Water Conservation 67(2).

USACE (US Army Corps of Engineers). 2011 Great Flood of '11. Our Mississippi. Rock Island, IL: US Army Corps of Engineers. http://www.mvs. usace.army.mil/Our\%20Mississippi/ourmississippi_su11_lowres.pdf. 